\title{
PERBANDINGAN PENGATURAN PENYELENGGARAN PENDIDIKAN PROFESI ADVOKAT (PPA) DI INDONESIA \\ DAN AMERIKA SERIKAT
}

\author{
Arif Setiawan \\ Lucky Suryo Wicaksono \\ Siti Anisah \\ Eko Rial Nugroho \\ Fakultas Hukum Universitas Islam Indonesia \\ Jl. Taman Siswa 158 Yogyakarta \\ Email: arifsetiawan_82@yahoo.com
}

\begin{abstract}
This research is intended to examine the organization of advocate professional education in Indonesia and United States as well as how the organization of advocate professional education should be applied in Indonesia. This research was conducted by normative method that analyzes the data with referring to the legal norms contained in legislation and judicial decisions as well as using a comparative approach (comparative law) to United States. The results show that the First, there are differences in the organization of Advocate Education in Indonesia and United States. Organization of advocate professional education in the United States conducted by the law school while in Indonesia carried out by the Advocates organization. Secondly, Advocates professional education in Indonesia should not be in the form of Special Education Advocate Profession (PKPA). Special Education Advocate Profession actually is a form of professional education. Professional Education as part of a higher education course should meet national standards of higher education.
\end{abstract}

Key words: organization of advocate professional, indonesia, united stated

\begin{abstract}
Abstrak
Advokat merupakan salah satu profesi hukum yang memiliki peran penting dalam system peradilan pidana Indonesia. Tulisan ini bertujuan untuk mengkaji pengaturan penyelenggaraan pendidikan profesi advokat di Indonesia dan Amerika Serikat serta bagaimana penyelenggaraan pendidikan profesi advokat yang seharusnya diterapkan di Indonesia. Tulisan ini merupakan hasil dari satu penelitian yang menggunakan metode penelitian hukum normatif dengan menggunakan menggunakan pendekatan perbandingan hukum (comparative law) terhadap Amerika Serikat. Hasil penelitian tersebut menunjukan bahwa penyelenggaraan Pendidikan Profesi Advokat di Amerika dilakukan oleh sekolah hukum sedangkan di Indonesia dilakukan oleh organisasi Advokat. Pendidikan profesi Advokat di Indonesia seharusnya bukan dalam bentuk Pendidikan Khusus Profesi Advokat. Pendidikan Profesi Advokat sejatinya merupakan bentuk pendidikan profesi. Pendidikan Profesi Advokat sebagai bagian dari pendidikan tinggi tentunya harus memunuhi standar nasional pendidikan tinggi.
\end{abstract}

Kata kunci: penyelenggaraan pendidikan advokat, indonesia, amerika 


\section{Latar Belakang}

Para pendiri Negara Kesatuan Republik Indonesia telah mencantumkan dalam Penjelasan UUD 1945 bahwa Negara Indonesia adalah berdasarkan atas Hukum (Rechtsstaat) dan tidak berdasarkan kekuasaan (Machsstaat). ${ }^{1}$ Keinginan dan citacitafounding fathers itu dalam Undang-Undang Dasar Negara Republik Indonesia (yang selanjutnya disebut dengan UUD NRI) Tahun 1945 menjadi UUD Negara Republik Indonesia Tahun 1945 diimplementasikan menjadi hukum dasar seperti yang dimaksud oleh Pasal 1 ayat (3), yang berbunyi bahwa "Negara Indonesia adalah negara hukum". Ketentuan ini mewajibkan kepada Pemerintahan Negara Republik Indonesia dan warga negaranya untuk menaati dengan tanpa membedakan kualitas dan kedudukannya untuk senantiasa tunduk dan taat kepada ketentuan hukum. Kewajiban ini merupakan suatu pemahaman bahwa hukum adalah sebagai panglima yang menjadi prinsip supremasi hukum. Hal itu sejalan dengan konsep negara hukum adalah negara yang kekuasaannya dibatasi oleh rule of law. Albert V. Dicey mengintrodusir tiga unsur dari rule of law, yaitu: Supremacy of Law; Equality before the Law; Human Rights. 2

Sejalan dengan konsep negara hukum tersebut, maka salah satu prinsip penting adalah jaminan kesederajatan bagi setiap orang di hadapan hukum (equality before the law). Hal ini tercermin dalam Pasal 27 ayat (1) UUD NRI Tahun 1945 yang menyatakan bahwa "segala warga negara bersamaan dengan kedudukannya di dalam hukum dan pemerintahan dan wajib menjunjung hukum dan pemerintahan itu dengan tidak ada kecualinya". ${ }^{3}$ Pasal tersebut dapat dimaknai bahwa setiap warga negara berhak atas pengakuan, perlindungan, jaminan dan kepastian hukum yang adil, serta perlakuan yang setara di hadapan hukum. Dalam usaha memperkuat prinsip tersebut maka salah satu substansi penting amandemen UUD NRI Tahun 1945 telah membawa perubahan yang mendasar dalam kehidupan ketatanegaraan khususnya dalam pelaksanaan kekuasaan kehakiman. Berdasarkan perubahan tersebut ditegaskan bahwa ketentuan badan-badan lain yang fungsinya berkaitan dengan kekuasaan kehakiman diatur dalam undang-undang. Badan-badan lain yang fungsinya berkaitan dengan kekuasaan kehakiman, salah satunya adalah Advokat.

Dalam usaha mewujudkan prinsipprinsip negara hukum dalam kehidupan bermasyarakat dan bernegara, peran dan fungsi Advokat sebagai profesi yang bebas, mandiri dan bertanggung jawab merupakan hal yang penting, selain lembaga peradilan dan

1 Azhari, Negara Hukum Indonesia, Analisis Yuridis Normatif tentang Unsur-unsurnya, (Jakarta: Ul-Press, 1995), hlm. 116.

2 Albert V. Dicey, Introduction to the Study of the Law of Consititution, 8th Revised Edition, (Liberty Fund Inc. 1 Januari 1982), p. 23.

3 Pasal 27 ayat (1) UUD Negara Republik Indonesia Tahun 1945. 
instansi penegak hukum seperti kepolisian dan kejaksaan. Melalui jasa hukum yang diberikan, Advokat menjalankan tugas profesinya demi tegaknya keadilan berdasarkan hukum untuk kepentingan masyarakat pencari keadilan, termasuk usaha memberdayakan masyarakat dalam menyadari hak-hak fundamentalnya di depan hukum. Advokat sebagai salah satu unsur sistem peradilan merupakan salah satu pilar dalam menegakkan supremasi hukum dan hak asasi manusia. ${ }^{4}$ Predikat profesi hukum yang melekat pada seorang advokat mengacu pada kualitas tanggung jawab terhadap tegaknya keadilan sebagai substansi dari hukum. Dengan demikian, seorang atau sekelompok profesional hukum dalam memberikan pelayanan jasa atau bantuan hukum bagi masyarakat akan berpedoman pada standar yang terus menjamin bahwa tidak akan melakukan kesalahan atau kelalaian yang merugikan pencari keadilan, melukai rasa keadilan masyarakat, mengingkari kebenaran hukum atau membohongi hati nuraninya sendiri. $^{5}$

Dalammewakili kepentingan dan membela hak-hak hukum klien (pencari keadilan dan kebenaran) maka advokat harus berpikir objektif berdasarkan keahlian yang dimiliki dan kode etik profesi. Advokat berkewajiban untuk utama untuk menegakan pendirian dan integritas profesinya dengan cara selalu berpegang pada etika. ${ }^{6}$ Profesi advokat itu mulia (Officium Nobile) karena mengabdikan diri kepada kepentingan masyarakat dan bukan pada dirinya sendiri, serta berkewajiban untuk ikut menegakkan hak asasi manusia. Advokat bebas dalam membela, tidak terikat pada perintah klien dan tidak pilih-pilih siapa lawan kliennya, apakah berasal dari golongan pejabat, pengusaha, penguasa, dan lain sebagainya. Sehingga profesi advokat dituntut untuk memiliki standar keahlian tertentu guna menjalankan profesinya dengan baik.

Salah satu cara untuk membentuk keahlian Advokat adalah melalui pendidikan profesi advokat. Berdasarkan Pasal 2 ayat (1) UU No.18 Tahun 2003 tentang Advokat (yang selanjutnya disebut dengan UU Advokat), pendidikan profesi advokat dilaksanakan oleh Organisasi Advokat. Lebih lanjut berdasarkan Pasal 32 ayat (4) UU Advokat, menyatakan bahwa dalam waktu paling lambat 2 (dua) tahun setelah berlakunya Undang-Undang ini, Organisasi Advokat harus telah terbentuk. Dalam rangka pemenuhan dan pelaksanaan ketentuan Pasal 32 ayat (4) tersebut, pada 21 Desember 2004 dideklarasikan berdirinya Perhimpunan Advokat Indonesia (Peradi) di Jakarta. Dengan demikian, Peradi menjadi organisasi Advokat satu-satunya yang menjadi wadah bagi profesi Advokat, sebagaimana yang diamanatkan dalam Pasal 28 ayat (1) UU Advokat.

4 Putusan Mahkamah Konstitusi No. 66/PUU-VIII/2010 hlm. 147.

5 Artidjo Alkostar, Peran dan Tantangan Advokat Dalam Era Globalisasi, (Yogyakarta: UII Press, 2010), hlm. 10 .

6 Jeffrey Pinsler, Ethics and Professional Responsibility, A Code For Advocate and Solicitor, (Singapore: Academy Publising, 2007), p. 49. 
Pembentukan Peradi dalam realitasnya menimbulkan ketidakpuasan dan polemik berkepanjangan pada beberapa anggota organiasasi advokat. Salah satu bentuk dari ketidakpuasan tersebut adalah lahirnya Deklarasi Kongres Advokat Indonesi (KAI). Dibentuknya KAI menimbulkan sengketa antara pengurus Peradi dengan pengurus KAI dan keduanya mengikrarkan diri sebagai national bar association sebagaimana diamanatkan oleh Pasal 28 ayat (1) UU Advokat. KAI menganggap pembentukan Peradi tidak sah karena pengangkatan pengurusnya dilakukan secara tidak transparan, tidak mengindahkan hak-hak anggota untuk memilih pengurusnya secara bebas, adil dan akuntabel. Sedangkan di sisi lain, pengurus Peradi menganggap keberadaan KAI bukanlah national bar association yang sah karena KAI dibentuk melampaui jangka waktu pembentukan organisasi tunggal advokat sebagaimana yang diamanatkan dalam UU Advokat. ${ }^{7}$

Menanggapi perkembangan tersebut, Mahkamah Agung telah mengeluarkan Surat Ketua Mahkamah Agung No. 052/ KMA/V/2009 tertanggal 1 Mei 2009 perihal Sikap Mahkamah Agung terhadap Organisasi
Advokat. Surat tersebut intinya menyatakan bahwa perselisihan mengenai organisasi advokat yang sah harus diselesaikan secara internal oleh para advokat sendiri. Mahkamah Agung meminta kepada para Ketua Pengadilan Tinggi untuk tidak terlibat baik secara langsung maupun tidak langsung dalam perselisihan tersebut. Mahkamah Agung memerintahkan kepada para Ketua Pengadilan Tinggi untuk tidak mengambil sumpah advokat baru, sebagaimana yang ditentukan dalam Pasal 4 UU Advokat. ${ }^{8}$ Hal ini menimbulkan dampak negatif terhadap organisasi advokat serta pada penyelenggaraan pendidikan profesi Advokat. Dampak negatif tersebut secara tidak langsung juga berdampak terhadap para pencari keadilan dan masyarakat ${ }^{9}$.

Konflik Organisasi advokat belum berakhir sampai di situ saja, UU Advokat memberikan kewenangan yang sangat luas terhadap organisasi advokat yang dalam hal ini Peradi. Peradi memiliki kewenangan untuk menyelenggarakan pendidikan, pengangkatan dan pengawasan terhadap Advokat. Kurangnya transparansi dalam menyelenggarakan kewenangan tersebut, serta ego-ego pribadi dari pengurus Peradi mengakibatkan pada Musyawarah Nasional

7 Pemohon pada Perkara No. 014/PUU-IV/2006 mengajukan pengujian terhadap Pasal 28A, Pasal 28C Ayat (2), Pasal 28D Ayat (1) dan Ayat (3), dan 8 Pasal 28E Ayat (3) UUD 1945, sedangkan pada Perkara No. 015/PUUIV/2006 yang diuji adalah Pasal 28C UUD.

8 Frans Hendra Winarta, "Konflik Antar Pengurus Organisasi Advokat yang Berkepanjangan", http://www. hukumonline.com/berita/baca/hol22359/konflik-antar-pengurus-organisasi-advokat-yang-berkepanjangan, diakses 12 Februari 2016.

9 Akibat dari perpecahan Peradi, persyaratan untuk menjadi advokat dipermudah oleh masing-masing organisasi sehingga berdampak kepada kualitas advokat. Hal tersebut meningkatkan potensi bahwa advokat tersebut melakukakan malpraktek dalam melakukan penangan ke pencari keadilan. 
II Peradi, kepengurusan pecah menjadi 3 kubu. ${ }^{10}$ Puncaknya Ketua Mahkamah Agung mengeluarkan Keputusan No. 73/KMA/ HK.01/IX/2015 yang intinya adalah Ketua Pengadilan Tinggi berwenang melakukan penyumpahan terhadap Advokat yang memenuhi Pasal 2 dan 3 UU Advokat tanpa melihat dari organisasi Advokat manapun. ${ }^{11}$

Dilihat dari kenyaataan tersebut bahwa pembentukan organisasi advokat di Indonesia selalu mengalami masalah. Permasalahan mengenai organisasi Advokat tentunya akan berimplikasi terhadap penyelenggaraan pendidikan khusus profesi advokat yang diselenggarakan oleh Peradi. Peradi yang seharusnya menjadi satu-satunya organisasi advokat yang diberikan kewenangan menyelenggarakan pendidikan khusus profesi advokatsudahmengalamiperpecahan. Dampak dari perpecahan tersebut adalah semakin tidak terstandarisasinya penyelenggaraan pendidikan advokat dikarenakan setiap kubu pecahan Peradi menyelenggarakan PKPA secara sendiri-sendiri.

Dengan demikian, tulisan ini bermaksud untuk mencari perbandingan pengaturan penyelenggaraan pendidikan bagi calon advokat sebagai suatu bagian dari penyelenggaraan pendidikan profesi yang seharusnya memiliki standar kompetensi untuk dapat melakukan penegakan hukum yang baik dan benar. Perbandingan penyelenggaraan program pendidikan profesi advokat dan peran organisasi advokat dalam penyelenggaraan pendidikan profesi advokat di Negara lain khususnya di Amerika Serikat. Diharapkan Indonesia dapat mengadopsi sistem penyelenggaraan profesi advokat di Negara lain dan dapat diaplikasikan di Indonesia, sehingga penyelenggaraan profesi advokat di Indonesia semakin baik dan organisasi advokat dapat berperan maksimal dalam menjalankan fungsinya dan perannya sebagai organisasi advokat demi terciptanya hukum yang dapat memberikan keadilan bagi para pencari keadilan (justitiable).

Tulisan ini bertujuan untuk mengetahui dan menganalisis: pertama, memahami pengaturan penyelenggaraan pendidikan profesi advokat di Indonesia dan di Amerika Serikat. Kedua, menemukan bentuk yang ideal penyelenggaraan pendidikan profesi advokat di Indonesia. Metode penelitian yang digunakan adalah metode penelitian normatif. Metode normatif digunakan untuk menganalisis data sekunder yang mengacu kepada norma-norma hukum yang terdapat dalam peraturan perundang-undangan dan putusan pengadilan, yaitu Putusan Mahkamah Konstitusi dan Putusan Mahkamah Agung, yang berkaitan dengan profesi advokat. ${ }^{12}$ Pendekatan yang dipergunakan untuk

\footnotetext{
10 Hendra Cipto, "Peradi Pecah Tiga, "Masing-Masing Kubu Punya Ketua Umum”, http://nasional.kompas. com/read/2015/03/28/09095281/Peradi.Pecah.Tiga.Masing-Masing.Kubu.Punya.Ketua.Umum, diakses 13 Februari 2016.

11 Surat Keputusan Mahkamah Agung No. 73/KMA/HK.01/IX/2015 tertanggal 23 Desember 2015.

12 Ronald Dworkin, Legal Research, (Daedalus: Spring, 1973), hlm. 250.
} 
menjawab persoalan yang telah dirumuskan tersebut adalah dengan menggunakan pendekatan perbandingan (comparative law). Perbandingan ini dilakukan dengan cara penafsiran antisipatif. Artinya perbandingan dilakukan dengan maksud untuk mencari hal-hal yang belum terungkap sebelumnya, sebagai bahan-bahan bagi sumber hukum material, yaitu bahan-bahan untuk membentuk peraturan perundang-undangan pada masa yang akan datang (futuristic). ${ }^{13}$ Dengan demikian, metode normatif ini mengacu pula kepada penelitian yang mengarah kepada argumentasi teoritis dan normatif atas penyelenggaraan pendidikan profesi advokat.

\section{Pembahasan}

\section{A. Penyelenggaraan Profesi Advokat di} Indonesia dan Amerika Serikat

\section{Penyelenggaraan pendidikan advokat di Indonesia}

Dasar hukum penyelenggaraan profesi di Indonesia diatur berdasarkan UndangUndang No. 12 Tahun 2012 tentang Pendidikan Tinggi (yang selanjutnya disebut dengan UU Pendidikan Tinggi). Berdasarkan UU Pendidikan Tinggi, terdapat 3 (tiga) jenis pendidikan tinggi yaitu pendidikan akademik, pendidikan vokasi, dan pendidikan profesi. Pendidikan profesi sebagaimana dinyatakan pada Pasal 17 ayat (1) undang- undang tersebut, Pendidikan Tinggi setelah program sarjana yang menyiapkan mahasiswa dalam pekerjaan yang memerlukan persyaratan keahlian khusus. Lebih lanjut lagi, Pasal 17 ayat (2) UU Pendidikan Tinggi menyatakan bahwa pendidikan profesi dapat diselenggarakan oleh Perguruan Tinggi dan bekerja sama dengan Kementerian, Kementerian Lain, dan atau organisasi profesi yang bertanggung jawab atas mutu layanan profesi. Pasal 24 ayat (1) UU Pendidikan Tinggi menegaskan bahwa program profesi merupakan pendidikan keahlian khusus yang diperuntukkan bagi lulusan program sarjana atau sederajat untuk mengembangkan bakat dan kemampuan memperoleh kecakapan yang diperlukan dalam dunia kerja.

Pengaturan lebih lanjut mengenai penyelenggaraan program profesi diatur dengan Peraturan Pemerintah dan Peraturan Menteri. Pasal 19 Peraturan Pemerintah No. 4 Tahun 2014 tentang Penyelenggaraan Pendidikan Tinggi dan Pengelolaan Perguruan Tinggi menyatakan bahwa sertifikat profesi merupakan pengakuan untuk melakukan praktik profesi yang diperoleh lulusan pendidikan profesi, spesialis, atau subspesialis. Sertifikat profesi tersebut diterbitkan oleh Perguruan Tinggi bersama dengan Kementerian, Kementerian Lain, Lembaga Pemerintah Non Kementerian (LPNK), dan/ atau Organisasi Profesi. Sedangkan Pasal

13 Matthew S. Raalf, “A Sheep in Wolf's Clothing: Why the Debate Surrounding Comparative Constitutional Law Is Spectacularly Ordinary," 73 Fordham L. Rev.: 1239, (Desember 2004): 1279-1281; Sujit Choudhry, "Globalization in Search of Justification: Toward a Theory of Comparative Constitutional Interpretation," 74 Ind. L. J. 819, (1999): 825-826. 
16 ayat (1) huruf e Peraturan Menteri Riset, Teknologi, dan Pendidikan Tinggi No. 44 Tahun 2015 tentang Standar Nasional Pendidikan Tinggi (Permenristekdikti tentang SNPT) menyatakan bahwa masa beban belajar penyelenggaraan program pendidikan profesi yaitu paling lama 3 (tiga) tahun akademik setelah menyelesaikan program sarjana atau program diploma empat/sarjana terapan, dengan beban belajar mahasiswa paling sedikit 24 (dua puluh empat) sks. Selanjutnya Pasal 17 ayat (3) Peraturan Pemerintah tersebut menyatakan bahwa mahasiswa program profesi dinyatakan lulus apabila telah menempuh seluruh beban belajar yang ditetapkan dan memiliki capaian pembelajaran lulusan yang ditargetkan oleh program studi dengan indeks prestasi kumulatif (IPK) lebih besar atau sama dengan 3,00 (tiga koma nol nol). Selanjutnya mahasiswa program profesi yang lulus berhak memperoleh sertifikat profesi.

Namun dalam penyelenggaraan pendidikan profesi advokat yang diselenggarakan oleh Peradi selama ini, belum sesuai dengan pengaturan pendidikan profesi sebagaimana diatur dalam Pasal 17 ayat (2) UU Pendidikan Tinggi jo Pasal 16 ayat (1) Permenristek tentang SNPT. Berdasarkan Pasal 2 ayat (1) UU Advokat, pendidikan profesi advokat dilaksanakan oleh Organisasi Advokat. Lebih lanjut berdasarkan Pasal 32 ayat (4) UU Advokat menyatakan bahwa dalam waktu paling lambat 2 (dua) tahun setelah berlakunya Undang-Undang ini, Organisasi Advokat telah terbentuk. Dalam rangka pemenuhan dan pelaksanaan ketentuan Pasal 32 ayat (4) tersebut, pada 21 Desember 2004 dideklarasikan berdirinya Perhimpunan Advokat Indonesia (Peradi) di Jakarta. Dengan demikian, Peradi menjadi organisasi Advokat satu-satunya yang menjadi wadah bagi profesi Advokat yang mana harus bertanggung jawab atas mutu layanan profesi, sebagaimana yang diamanatkan dalam Pasal 28 ayat (1) UU Advokat.

Eksistensi Peradi sebagai satu-satunya Organisasi Advokat juga diakui oleh negara, sedemikian berdasarkan pertimbangan putusan Mahkamah Konstitusi No. 66/PUU-VIII/2010 yang juga menguji Pasal 28 ayat (1) UU No. 18 Tahun 2003 dikaitkan dengan juga dengan Putusan MK No. 14/PUU-IV/2006 yang dalam Pertimbangan Putusan Perkara No 66/ PUU-VIII/2010 yang mana telah dengan jelas dimuat: "Bahwa mengenai pengujian Pasal 32 ayat (4) UU No. 18 Tahun 2003 telah pernah dimohonkan pengujian dan telah diputus oleh Mahkamah dalam Putusan Nomor 014/PUU-IV/2006, tanggal 30 November 2006 tersebut di atas. Mahkamah dalam pertimbangannya antara lain menyatakan, "Bahwa Pasal 32 ayat (3) dan ayat (4) UU Advokat sesungguhnya merupakan pasal yang sudah selesai dilaksanakan dengan telah berlalunya tenggat dua tahun dan dengan telah terbentuknya Peradi sebagai Organisasi Advokat yang merupakan satu-satunya wadah 
profesi Advokat, sehingga tidak relevan lagi untuk dipersoalkan konstitusionalitasnya". ${ }^{14}$

Lebih lanjut lagi dalam pertimbangannya, Mahkamah Konstitusi menyatakan bahwa "karena Pasal 28 ayat (1) UU Advokat menyebutkan, Organisasi Advokat merupakan satu-satunya wadah profesi Advokat yang bebas dan mandiri yang dibentuk sesuai dengan ketentuan UndangUndang ini, dengan maksud dan tujuan untuk meningkatkan kualitas profesi Advokat, maka organisasi Peradi sebagai satu-satunya wadah profesi Advokat pada dasarnya adalah organ negara dalam arti luas yang bersifat mandiri (independent state organ) yang juga melaksanakan fungsi negara (vide Putusan Mahkamah Nomor 066/PUU-II/2004)" 15

Implikasi dari diakuinya Peradi sebagai satu-satunya wadah profesi Advokat sebagaimana dimaksud dalam UU Advokat maka Peradi menjadi satu-satunya wadah profesi Advokat yang memiliki wewenang untuk: ${ }^{16}$

a. melaksanakan pendidikan khusus profesi Advokat [Pasal 2 ayat (1)];

b. pengujian calon Advokat [Pasal 3 ayat (1) huruf f];

c. pengangkatan Advokat [Pasal 2 ayat (2)];

d. membuat kode etik [Pasal 26 ayat (1)];

e. membentuk Dewan Kehormatan [Pasal 27 ayat (1)]; f. membentuk Komisi Pengawas [Pasal 13 ayat (1)];

g. melakukan pengawasan [Pasal 12 ayat (1)], dan;

h. memberhentikan Advokat [Pasal 9 ayat (1)];

UU Advokat tidak memastikan apakah wadah profesi advokat lain yang tidak menjalankan wewenang-wewenang tersebut berhak untuk tetap eksis atau tetap dapat dibentuk. Memperhatikan seluruh ketentuan dan norma dalam UU Advokat serta kenyataan pada wadah profesi Advokat, Mahkamah Konsitusi berpendapat bahwa satu-satunya wadah profesi Advokat yang dimaksud adalah hanya satu wadah profesi Advokat yang menjalankan 8 (delapan) kewenangan a quo, yang tidak menutup kemungkinan adanya wadah profesi advokat lain yang tidak menjalankan 8 (delapan) kewenangan tersebut berdasarkan asas kebebasan berkumpul dan berserikat menurut Pasal 28 dan Pasal 28E ayat (3) UUD 1945. Hal ini diperkuat dengan fakta bahwa dalam pembentukan Peradi, 8 (delapan) organisasi advokat yang ada sebelumnya tidak membubarkan diri dan tidak meleburkan diri pada Peradi; ${ }^{17}$

Terkait dengan kewenangan Organisasi Advokat tersebut diatas, Peradi mempunyai kewenangan absolut untuk melaksanakan pendidikan profesi Advokat. Berdasarkan

14 Putusan Mahkamah Konstitusi No. 66/PUU-VII/2010, hlm. 343.

15 Ibid., hlm. 153.

16 Ibid., hlm. 342.

17 Ibid. 
Peraturan Peradi No. 3 tahun 2006 tentang Penyelenggarakan Pendidikan Khusus Profesi Advokat diatur bahwa Peradi dapat bekerjasama dengan pihak lain untuk melaksanakan PKPA. Setiap institusi/ lembaga yang ingin menjadi mitra Peradi dalam pelaksanaan PKPA (mitra pelaksana PKPA) harus mendapat persetujuan terlebih dahulu dari Peradi yang tertuang dalam surat perjanjian. ${ }^{18}$

Pada kenyataanya yang diterapkan sampai saat ini adalah Peradi memegang kewenangan penuh dalam menentukan penyelenggaraan pendidikan profesi advokat dan bekerjasama dengan lembaga/institusi yang telah mempunyai izin sebagai lembaga penyelenggara pendidikan formal atau non-formal dari Menteri. Sehingga untuk menjadi Advokat, calon Advokat harus melewati tahapan-tahapan sebagai berikut:

1. Mengikuti Pendidikan Khusus Profesi Advokat (PKPA);

2. Mengikuti dan Lulus Ujian Profesi Advokat (UPA);

3. Mengikuti Magang di Kantor Advokat;

4. Pengangkatan dan Sumpah Advokat di Pengadilan Tinggi.

\section{Penyelenggaraan pendidikan advokat} di Amerika Serikat

Pendidikan hukum di dunia telah meluas secara signifikan pada akhir abad 20. Pendidikan hukum di Amerika Serikat menjadi model pendidikan hukum yang berpengaruh bagi negara-negara lain di dunia. Pada awal abad ke 20, pendidikan hukum di Amerika Serikat berubah dari model pelatihan magang (tidak formal) menjadi model pendidikan yang formal profesional. ${ }^{19}$ Pendidikan hukum memegang peran yang sangat penting karena tidak hanya memberikan pengajaran terkait dengan analisis hukum, hukum substantif dan keahlian di bidang hukum tetapi juga beberapa aspek nilai dan norma. Pendidikan hukum juga merupakan jembatan bagi ahli hukum yang akan berpraktek sebagai Advokat.

Tujuan dari program pendidikan hukum berdasarkan Standard 301 tentang Standards and Rules of Procedure for Approval of Law Schools (bentuk revisi) American Bar Association tahun 2015-2016 yaitu: ${ }^{20}$

a. sekolah hukum harus memelihara program ketat dari pendidikan hukum yang mempersiapkan mahasiswanya, setelah lulus, untuk dapat masuk ke "bar"

18 Pasal 3 ayat 1 Peraturan Peradi Nomer 3 Tahun 2006 tentang Penyelenggaraan Pendidikan Khusus Profesi Advokat.

19 American Bar Association, "History of the American Bar Association”, http://www.americanbar.org/content/ aba/about the_aba/history.html, diakses 25 Juni 2016.

20 American Bar Association, "ABA Standard and Rules of Procedure for Approval of Law Schools 2015-2016", http://www.americanbar.org/content/dam/aba/publications/misc/legal_education/Standards/2015_2016_ chapter_3.authcheckdam.pdf, diakses 25 Juni 2016. 
dan berpartisipasi efektif, beretika, serta bertanggung jawab sebagai anggota dari profesi hukum;

b. sekolah hukum harus membentuk dan menghasilkan hasil pembelajaran yang dirancang untuk mencapai tujuan tersebut.

Advokat di Amerika tergabung dalam American Bar Association (ABA), untuk wilayah nasional, sedangkan di tingkat negara bagian terdapat State Bar Association dan Local Bar Association di yurisdiksi masingmasing. Kegiatan terpenting dari ABA adalah pengaturan standar akademik untuk sekolah hukum serta perumusan model kode etik yang berkaitan dengan profesi hukum. Standar akademik tersebut digunakan untuk sekolah hukum yang memberikan pendidikan hukum maupun persyaratan untuk masuk ke Bar Association. $^{21}$

Amerika Serikat sebagai negara yang menganut sistem federal, memiliki aturan sendiri terkait dengan pendidikan hukum bagi para Advokat (attorney at law). Lisensi atau izin untuk berpraktik hukum diperoleh dari negara bagian bukan dari pemerintah federal. Kewenangan untuk memberikan lisensi tersebut ada pada Mahkamah Agung suatu negara bagian. Untuk menjadi seorang pengacara di Amerika, seorang sarjana hukum harus memenuhi langkah-langkah berikut:22

1. lulus dari sekolah hukum terakreditasi oleh ABA (American Bar Association);

2. mengisi permohonan secara rinci sehingga memungkinkan "bar" untuk melakukan evaluasi "character and fitness"; 23

Mayoritas yurisdiksi telah menerbitkan Character and Fitness Standards namun ada beberapa yurisdiksi yang tidak menerapkannya yaitu Alabama, California, Delaware, District of Columbia, Hawai, Lowa, Maine, Maryland, New York, Oklahoma, Pennsylvania, Tennessee, West Virginia, N. Mariana Islands, Palau, Puerto Rico, Virgin Islands sedangkan yurisdiksi lainnya telah menerbitkan Character and Fitness Standards. Pemohon yang melakukan tindak pidana tidak diperkenankan atau tidak akan memenuhi syarat untuk masuk BAR. Untuk mengevaluasi Character and Fitness Standards, dapat dilakukan oleh otoritas yurisdiksi yang berwenang atau badan lain yang terpisah dari Board

21 Ibid.

22 Judith A. McMorrow, Comparative Legal Education: An Introduction to US Legal Education and Preparation for the Practice of Law, (Boston College Law School: Electronic Copy, 2009), dalam http://ssrn.com/ abstract $=2076718$, diakses 18 Juli 2016.

23 Character and Fitness Standard merupakan sebuah standar moral yang diterapkan oleh yurisdiksi untuk mengetahui karakter dan moral para pelamar yang ingin masuk ke bar. Pelamar harus menunjukan bahwa mereka memiliki kualitas personal yang baik yang dibutuhkan untuk berpraktek hukum dan mempunyai karakter yang diperlukan menjustifikasi kebenaran dan keyakinan klien. Character and fitness juga digunakan untuk menguji pelamar bahwa mereka jujur, berintegritas, dapat dipercaya, rajin, dapat diandalkan, dalam New York State Assitance Trust, “Are You Fit To Be A Lawyer”, http://www.nylat.org/publications/brochures/ documents/characterandfitnessbrochure09.pdf, diakses 5 Agustus 2016. 
of Examiners. Setiap negara akan mewajibkan pemohon masuk BAR untuk mengungkapkan informasi yang relevan dengan Character and Fitness pemohon. Penemuan salah satu dari berikut harus diperlakukan sebagai penyebab untuk penyelidikan lebih lanjut sebelum BAR memeriksa untuk memutuskan apakah pemohon memiliki Character and Fitness untuk praktek hukum sebagai berikut: ${ }^{24}$

a. tindakan melawan hukum;

b. pelanggaran akademik;

c. pembuatan laporan palsu, termasuk kelalaian;

d. kesalahan dalam pekerjaan;

e. tindakan yang melibatkan ketidakjujuran, penipuan atau kekeliruan;

f. penyalahgunaan proses hukum;

g. mengabaikan tanggung jawab keuangan;

h. mengabaikan kewajiban professional;

i. pelanggaran perintah pengadilan;

j. bukti ketidakstabilan mental atau emosional;

k. bukti ketergantungan obat atau alkohol;

1. penolakan masuk ke bar di wilayah hukum lain terkait dengan alasan Character and Fitness;

m.tindakan disipliner oleh lembaga disiplin pengacara atau disiplin profesional lembaga yurisdiksi lainnya.

3. lulus ujian "bar" (Uniform bar Examination); dan

Uniform Bar Examination (UBE) adalah ujian untuk masuk Bar yang telah terstandarisasi. UBE dikembangkan oleh National Conference of Bar Examiners atau NCBE (Konferensi Nasional Penguji). UBE terdiri dari Multistate Bar Examination (MBE), Multistate Essay Examination (MEE) dan Multistate Performance Test (MPT) dan juga menawarkan portabilitas skor (nilai) lintas negara. Tujuan dari UBE adalah untuk menguji pengetahuan dan kecakapan setiap pengacara yang mana harus mampu menunjukan hal tersebut sebelum mendapatkan lisensi untuk berpraktik. Hasil dari UBE berupa nilai portable "portable score" yang dapat digunakan untuk mendaftar di selain yurisdiksi UBE. Dengan mengikuti UBE maka para pengacara dapat dengan lebih mudah untuk berpraktik melampaui lintas batas negara. Namun, mahasiswa/pelamar yang telah lulus UBE tidak akan secara otomatis dapat mengikuti ujian bar di negara-negara lain yang juga mengadopsi UBE. Hal ini dikarenakan negara-negara akan menetapkan nilai kelulusannya sendiri dan juga dapat memutuskan

24 National Conference of Bar Examiners and the American Bar Association., Comprehensive Guide to Bar Admission requairement 2015, National Bar Examiner and American bar Association Section of Legal Education And Admissions To The Bar, p. viii. 
menerima hasil tes hanya untuk waktu yang terbatas.

Saat ini terdapat 205 institusi yang disetujui oleh ABA untuk menyelenggarakan pendidikan hukum. Sejumlah 204 merupakan sekolah hukum yang menganugerahkan gelar Juris Doctor, dan 1 lainnya adalah U.S Army Judge Advocate General's School. Sekolah hukum tersebut harus menghasilkan lulusan yang minimum harus memiliki kompetensi sebagai berikut: ${ }^{25}$

a. pengetahuan dan pemahaman tentang hukum secara substantif dan prosedural;

b. analisis dan penalaran hukum, penelitian hukum, legal problem solving, serta komunikasi tertulis dan lisan dalam konteks hukum;

c. bertanggung jawab secara profesional dan beretika secara layak terhadap klien dan sistem hukum; dan

d. kemampuan profesional lainnya, ${ }^{26}$ yang dibutuhkan untuk berpartisipasi secara kompeten dan beretika sebagai anggota dari profesi hukum.

Selain itu, sekolah hukum tersebut juga harus memenuhi standar kurikulum yang telah ditentukan dalam Standards for Approval of Law School (Revised Standart 2015-2016), yaitu: ${ }^{27}$ a. Sekolah hukum harus menawarkan kurikulum yang mengharuskan setiap siswa dapat menyelesaikan dengan baik hal-hal sebagai berikut:

1. satu mata kuliah dari 2 SKS dalam hal tanggung jawab profesional yang mencakup pengajaran yang substantial tentang sejarah, tujuan, struktur, nilainilai, dan tanggung jawab profesi hukum serta para anggotanya;

2. satu pengalaman menulis di tahun pertama dan setidaknya satu pengalaman menulis tambahan setelah tahun pertama, yang keduanya di bawah pengawasan fakultas;

3. satu atau lebih program eksperiensial, ${ }^{28}$ dengan total minimal 6 SKS. Program eksperiensial ini harus menjadi program simulasi sebuah klinik hukum atau penempatan langsung di lapangan. Untuk memenuhi persyaratan, program ini harus menjadi eksperiensial secara alami dan harus:

a) mengintegrasikan doktrin, teori, keterampilan, dan etika hukum, dan melibatkan para siswa dalam kinerja dari satu atau

25 American Bar Association, "ABA Standard and Rules of Procedure for Approval of Law Schools 2015-2016", op.cit., diakses 27 Juli 2016.

26 Kemampuan profesional lainnya akan ditentukan oleh sekolah hukum, yang dapat mencakup seperti wawancara, konseling, negosiasi, pengembangan fakta dan analisis, praktik di persidangan, penyusunan dokumen, penanganan perselisihan, organisasi dan manajemen, kerjasama, cultural competence (kesatuan atau kongruensi antara perilaku, sikap, kebijakan yang datang bersama-sama dalam sebuah sistem, lembaga atau kalangan profesional dan memungkinkan sistem, lembaga atau profesi tersebut untuk bekerja secara efektif dalam situasi lintas budaya), dan kemampuan self-evaluation.

27 American Bar Association, op.cit., diakses 27 Juli 2016.

28 Program pembelajaran melalui pengalaman, atau mengajarkan teori yang dikontekskan dengan praktik secara langsung, lebih khusus didefinisikan "reflection on doing". 
lebih kemampuan profesional sebagaimana diidentifikasi dalam Standard 302;

b) mengembangkan konsep yang mendasari kemampuan profesional yang diajarkan;

c) memberikan kesempatan berganda untuk bekerja; dan

d) memberikan kesempatan untuk self-evaluation.

b. Sekolah hukum harus memberikan kesempatan besar bagi para siswanya untuk:

1. Mengambil bagian dalam klinik hukum atau penempatan atau terjun langsung di lapangan; dan

2. Partisipasi siswa dalam layanan hukum pro bono, termasuk kegiatan pelayanan publik yang berhubungan dengan hukum.

Penjelasan Standar 303-1 menyebutkan bahwa sekolah hukum tersebut tidak dapat memberikan izin kepada siswa-siswanya menggunakan satu program kursus untuk memenuhilebihdarisatupersyaratan.Misalnya, program yang mencakup pengalaman menulis digunakan untuk persyaratan kelas selanjutnya tidak dapat dihitung sebagai satu program eksperiensial sebagaimana disyaratkan dalam Standar 303(a)(3). Selanjutnya, faktor yang dipertimbangkan dalam menilai pengalaman menulis siswa antara lain jumlah dan sifat dari tulisan yang ditugaskan, bentuk dan tingkat penilaian individual dari produk tulisan siswa dan jumlah draft yang harus dihasilkan oleh seorang siswa untuk pengalaman menulis apapun. $^{29}$

Aturan 6.1 dari ABA Model Rules of Professional Conduct mendorong para pengacara untuk memberikan pelayanan hukum pro bono terutama untuk orang dengan keterbatasan dana atau organisasi yang melayani orang-orang tersebut. Selain itu, pengacara juga didorong untuk memberikan pro bono terkait pelayanan publik. Dalam memenuhi persyaratan sebagaimana dalam Standard 303 (b)(2), sekolah-sekolah hukum didorong untuk memberikan kesempatan bagi siswa layanan pro bono dengan menyertakan prioritas dalam Aturan 6.1. Kemudian, sekolah-sekolah hukum juga didorong untuk memprmosikan kesempatan bagi mahasiswanya lebih dari karir sekolah hukum mereka, setidaknya 50 jam layanan pro bono sesuai dengan Standard 303 (b) (2). Pro bono dan kesempatan pelayanan publik tidak harus terstruktur untuk mencapai hasil yang dibutuhkan oleh Standard 302 (b) (2). Standard 302 (b)(2) tidak menghalangi masuknya kegiatan pemberian kredit dalam program sekolah hukum yang berkaitan dengan kesempatan pro bono selama kegiatan non-SKS yang berhubungan dengan hukum merupakan bagian dari program itu.

Kegiatan pelayanan publik yang berhubungan dengan hukum yang dimaksud mencakup:

a. membantu kelompok atau organisasi yang mencari perlindungan hukum atau untuk melindungi hak-hak sipil, kebebasan sipil, atau hak-hak masyarakat;

29 Interpretation 303-2 of Standards for Approval..., op.cit., hlm. 16. 
b. memberikan bantuan sosial, organisasi keagamaan, warga negara, masyarakat, pemerintah, dan organisasi pendidikan yang tidak mampu membayar bantuan hukum;

c. berpartisipasi dalam kegiatan memberikan informasi tentang keadilan, hukum atau sistem hukum bagi mereka yang mungkin tidak memiliki informasi tersebut; dan

d. terlibat dalam kegiatan untuk meningkatkan kapasitas hukum dan lembaga hukum untuk berbuat adil.

Sebagaimana telah dijelaskan sebelumnya, bahwa untuk berpraktik hukum, seorang Advokat harus melalui ujian BAR di masing-masing yurisdiksi. Dalam hal ini
ABA telah menerbitkan Comprehensive Guide to BAR Admission Requirements (Panduan Komprehesif mengenai Persyaratan untuk Masuk BAR) Tahun 2016. Panduan ini merupakan edisi yang telah diperbaharui dari panduan sebelumnya yang dirilis pada tahun 2015. Publikasi ini merupakan hasil kerjasama dari National Conference of BAR Examiners, ABA Section on Legal Education and Admissions to the BAR, yang berisi rekomendasi untuk penerimaan masuk ke BAR Association serta data terkait

Secara garis besar terdapat perbedaan dari segi penyelanggaraan Pendidikan Advokat di Indonesia dan Amerika Serikat yang mana tertuang dalam uraian sebagai berikut:

Tabel 1. Perbandingan Penyelenggaraan Pendidikan Advokat Di Indonesia dan Amerika Serikat

\begin{tabular}{|c|c|c|c|}
\hline No. & Keterangan & Di Indonesia & Di Amerika Serikat \\
\hline 1. & $\begin{array}{l}\text { Pelaksana } \\
\text { Pendidikan } \\
\text { Profesi } \\
\text { Advokat }\end{array}$ & $\begin{array}{l}\text { Diselenggarakan oleh Organisasi Advokat } \\
\text { / Peradi }\end{array}$ & $\begin{array}{l}\text { Diselenggarakan Oleh } \\
\text { Sekolah Hukum / } \\
\text { Perguruan Tinggi }\end{array}$ \\
\hline 2. & $\begin{array}{l}\text { Kurikulum } \\
\text { Pendidikan } \\
\text { Advokat }\end{array}$ & $\begin{array}{l}\text { Ditentukan Oleh Organisasi Advokat/ } \\
\text { Peradi berdasarkan Peraturan Peradi No. } \\
3 \text { tahun } 2006 \text { tentang Penyelenggarakan } \\
\text { Pendidikan Khusus Profesi Advokat }\end{array}$ & $\begin{array}{l}\text { Ditentukan oleh } \\
\text { Organisasi Advokat } \\
\text { federal / American bar } \\
\text { Association melalui } \\
\text { Standards for Approval } \\
\text { of Law School (Revised } \\
\text { Standard 2015-2016) }\end{array}$ \\
\hline 3 & $\begin{array}{l}\text { Ujian } \\
\text { Kompetensi }\end{array}$ & $\begin{array}{l}\text { Diselanggarakan Oleh Organisasi Advokat } \\
\text { /Peradi yang dikenal sebagai Ujian Profesi } \\
\text { Advokat (UPA) }\end{array}$ & $\begin{array}{l}\text { Diselenggarakan oleh } \\
\text { Organisasi Advokat } \\
\text { Federal /negara bagian } \\
\text { yang dikenal dengan } \\
\text { Uniform Bar Examination } \\
\text { (UBE) }\end{array}$ \\
\hline 4 & $\begin{array}{l}\text { Persyaratan } \\
\text { tambahan } \\
\text { sebelum } \\
\text { pengangkutan } \\
\& \text { sumpah }\end{array}$ & $\begin{array}{l}\text { Magang selama } 2 \text { Tahun di kantor } \\
\text { Advokat, Tidak Pernah terlibat dalam } \\
\text { kasus Pidana dibuktikan dengn Surat } \\
\text { catatan Kepolisian (SKCK) dan Surat } \\
\text { Keterangan Bebas Perkara dari Pengadilan } \\
\text { Negeri sesai dengan Domisili calon } \\
\text { Advokat }\end{array}$ & $\begin{array}{l}\text { Wajib lulus dari } \\
\text { Character and Fitness } \\
\text { Standards Requirement }\end{array}$ \\
\hline
\end{tabular}




\section{B. Penyelenggaraan \\ Pendidikan \\ Profesi Advokat Yang Seharusnya Diberlakukan di Indonesia}

Peradi sebagai organisasi advokat yang dibentuk berdasarkan amanat UU Advokat sebagai wadah tunggal organisasi advokat yang diberikan kewenangan multak untuk menyelenggarakan pendidikan profesi Advokat sudah tidak berjalan sesuai dengan harapan Peradi sebagai satu-satunya wadah profesi Advokat pada dasarnya adalah organ negara dalam arti luas yang bersifat mandiri (independent state organ) yang juga melaksanakan fungsi negara. Sebagaimana diamanatkan dalam Pasal 28 ayat (1) UU Advokat bahwa pembentukan Organisasi Advokat yang bebas dan mandiri dalam hal ini adalah Peradi adalah dengan maksud dan tujuan untuk meningkatkan kualitas profesi Advokat.

Berdasarkan pasal 3 ayat (1) UU No.18 Tahun 2003, kewenangan yang diberikan kepada Peradi juga meliputi melakukan pengujian calon Advokat yang mana ujian tersebut merupakan ujian mengetahui sejauh mana kompetensi calon Advokat. Pengujian calon advokat tersebut dikenal dengan Ujian Profesi Advokat (UPA). Dengan demikian, Peradi seharusnya dapat menjaga standar kompetensi dan mutu para calon Advokat. Namun pada kenyataannya, konflik internal yang terjadi didalam tubuh Peradi yang masih berkepanjangan hingga saat ini memberikan implikasi negatif terhadap standar kompetensi dan kualitas calon Advokat.
Secara Ideal, Pendidikan Profesi Advokat sebagai bagian dari Pendidikan Tinggi seharusnya dalam pelaksanaannya harus tetap mengacu pada Permenristekdikti tentang SNPT. Di dalam Permenristekdikti tersebut diatur mengenai standar minimal yang harus dipenuhi dalam penyelenggaraan pendidikan profesi sebagaimana ketentuan dalam Pasal 16 ayat (1) huruf e yang menyatakan bahwa masa beban belajar penyelenggaraan program pendidikan profesi yaitu paling lama 3 (tiga) tahun akademik setelah menyelesaikan program sarjana atau program diploma empat/sarjana terapan, dengan beban belajar mahasiswa paling sedikit 24 (dua puluh empat) sks.

Lebih lanjut lagi berdasarkan Pasal 17 ayat (1) Permenristekdikti tentang SNPT mengatur bahwa 1 (satu) sks pada proses pembelajaran berupa kuliah, responsi atau tutorial, terdiri atas:

a. kegiatan tatap muka 50 (lima puluh) menit per minggu per semester;

b. kegiatan penugasan terstruktur 60 (enam puluh) menit per minggu per semester dan

c. kegiatan mandiri 60 (enam puluh) menit per minggu per semester.

Namun pada kenyataannya penyelanggaraan PKPA yang dilakukan selama ini hanya berjalan dalam waktu kurang lebih 1-3 bulan tergantung dari mitra penyelenggara PKPA yang telah disetujui oleh Peradi. Dengan singkatnya waktu penyelenggaraan PKPA tersebut tentunya berdampak pada belum 
terpenuhinya standar sebagaimana disebutkan diatas. Sehingga Pendidikan Khusus Profesi Advokat (PKPA) yang berjalan saat ini belum memenuhi standar minimal pendidikan profesi berdasarkan Permenristekdikti tentang SNPT.

Terkait dengan kompetensi pendidikan profesi, berdasarkan lampiran Permenristekdikti tentang SNPT, Lulusan Program Profesi wajib memiliki: ${ }^{30}$

1. mampu bekerja di bidang keahlian pokok untuk jenis pekerjaan yang spesifik dan memiliki kompetensi kerja yang minimal setara dengan standar kompetensi kerja profesinya;

2. mampu membuat keputusan yang independen dalam menjalankan pekerjaan profesinya berdasarkan pemikiran logis, kritis, sistematis, dan kreatif;

3. mampu mengomunikasikan pemikiran/ argumen atau karya inovasi yang bermanfaat pengembangan profesi dan kewirausahaan, yang dapat dipertanggungjawabkan secara ilmiah dan etika kepada masyarakat terutama masyarakat profesinya;

4. mampu melakukan evaluasi secara kritis terhadap hasil kerja dan keputusan yang dibuat dalam melaksanakan pekerjaannya oleh dirinya sendiri dan oleh sejawat;

5. mampu meningkatkan keahlian keprofesiannya pada bidang yang khusus melalui pelatihan dan pengalaman kerja;

6. mampu meningkatkan mutu sumber daya untuk pengembangan program strategis organisasi;
7. mampu memimpin suatu tim kerja untuk memecahkan masalah pada bidang profesinya;

8. mampu bekerja sama dengan profesi lain yang sebidang dalam menyelesaikan masalah pekerjaan bidang profesinya;

9. mampu mengembangkan dan memelihara jaringan kerja dengan masyarakat profesi dan kliennya;

10. mampu bertanggungjawab atas pekerjaan di bidang profesinya sesuai dengan kode etik profesinya;

11. mampu meningkatkan kapasitas pembelajaran secara mandiri;

12. mampu berkontribusi dalam evaluasi atau pengembangan kebijakan nasional dalam rangka peningkatan mutu pendidikan profesi atau pengembangan kebijakan nasional pada bidang profesinya; dan mampu mendokumentasikan, menyimpan, mengaudit, mengaman-kan, dan menemukan kembali data dan informasi untuk keperluan pengembangan hasil kerja profesinya.

Berdasarkan standar kompetensi lulusan program profesi tersebut diatas, tentunya tidak dapat dicapai dengan model pendidikan yang singkat. Pendidikan PKPA yang bukan hanya untuk menyiapkan calon Advokat menghadapi Ujian Profesi Advokat melainkan menyiapkan standar lulusan profesi yang kompeten sehingga siap untuk menjadi seorang Advokat yang handal. Hal tersebut

30 Lampiran Peraturan Menteri Riset, Teknologi, dan Pendidikan Tinggi No. 44 Tahun 2015 tentang Standar Nasional Pendidikan Tinggi. 
diperburuk dengan adanya konflik yang berkepanjangan didalam tubuh Peradi yang semakin mengurangi standarisasi kompetensi dan mutu calon advokat. Hal tersebut ditandai dengan masing-masing kubu pecahan dari Peradi menyelenggarakan Ujian Profesi Advokat masing-masing sehingga disinyalir bahwa standarisasi daripada Ujian profesi tersebut tidak seragam.

Pendidikan Profesi Advokat sejatinya merupakan pendidikan profesi yang bertujuan pada penguasaan pengetahuan dan kecakapan kompetensi untuk berpraktek. Pendidikan Profesi lebih diarahkan pada menghasilkan tenaga profesional yang memiliki kemampuan kecakapan atau kompetensi standar dan kinerja standar. Sehingga untuk menjamin mutu pendidikan Advokat tentunya harus sesuai dengan Kerangka Kulaifikasi Nasional Indonesia (KKNI) sebagaimana diatur berdasarkan Peraturan Presiden No. 8 Tahun 2012 tentang Kerangka Kualifikasi Nasional.

Pemberian kewenangan terhadap organisasi Advokat (dalam hal ini Peradi) dalam penyelenggaraan pendidikan profesi Advokat serta sertifikasi profesi Advokat tentunya harus bisa dipertanggungjawabkan. Peradi harus mengontrol kompetensi dan kualitas dari Advokat agar fungsi dari pada Advokat sebagai salah satu penegak hukum bisa berjalan dengan baik. Standarisasi dan mutu profesi advokat harus jelas dan selalu dijaga oleh Peradi. Namun pada kenyataannya kewajiban tersebut belum dilaksanakan dengan baik oleh Peradi.
Jika dibandingkan dengan penyelenggaraan Pendidikan Profesi Advokat di Amerika, Organisasi Advokat di Amerika yang dalam hal ini adalah American Bar Association (ABA) memiliki keweangan yang berbeda dengan Peradi. ABA berperan dalam menentukan standar kompetensi dan mutu dari calon Advokat dengan melalaui Standarisasi Kurikulum Pendidikan Advokat di Amerika. ABA secara periodik menentukan dan selalu memperbaharui standar kurikulum profesi advokat ke sekolah-sekolah hukum di Amerika, atau yang dikenal dengan Standard 301 tentang Standards and Rules of Procedure for Approval of Law Schools. ${ }^{31}$

Guna memperbaiki keadaan tersebut, PKPA harus ditranformasikan menjadi Pendidikan Profesi Advokat yang sesuai dengan standar nasional pendidikan tinggi. Pendidikan Profesi Advokat yang dilakukan sesuai dengan standar yang telah ditentukan dalam standar nasional perguruan tinggi. Sehingga nantinya pendidikan profesi adavokat bukan lagi menjadi pendidikan khusus profesi yang hanya berlangsung dalam waktu singkat melainkan sesuai dengan beban belajar sebagaimana diatur dalam Pasal 16 ayat (1) huruf e Permenristekdikti tentang SNPT.

Perubahan tersebut bisa dilakukan dengan cara merevitalisasi keweangan Peradi dalam penyelenggaraan pendidikan profesi advokat. Memberikan kewenangan penyelenggaraan pendidikan profesi terhadap perguruan tinggi 
untuk menyelenggarakan pendidikan profesi advokat untuk mendidik para calon advokat agar menghasilkan lulusan yang memiliki standar kompetensi dan kualitas sebagai seorang advokat. Hal tersebut bisa dilakukan dengan cara menjudicial reviewmelakukan uji materiil pPasal pasal 2 ayat (1) UU Advokat ke Mahkamah Konstitusi atau melalui amandemen UU Advokat melalui legislatif. Sehingga nantinya Peradi hanya diberikan kewenangan untuk menentukan kurikulum pendidikan profesi advokat kepada Perguruan tinggi hukum yang menyelenggarakan pendidikan profesi advokat. Lebih lanjut lagi, Peradi tetap memiliki kewenangan untuk menyelenggarakan ujian profesi advokat (UPA) dengan lebih selektif sehingga nantinya calon advokat yang telah lulus UPA memiliki kompetensi yang cukup, beretika, serta bertanggung jawab terhadap profesinya dan masyarakat.

\section{Simpulan}

1. Terdapat perbedaan penyelenggaraan pendidikan Advokat di Indonesia dengan Di Amerika Serikat. Penyelenggaraan pendidikan Advokat di Indonesia dilaksanakan sepenuhnya oleh Organisasi Advokat yang dalam hal ini adalah Peradi. Peradi mempunyai kewenangan mutlak dalam menyelenggarakan Pendidikan Khusus Profesi Advokat, menentukan kurikulum pendidikan Advokat, hingga melaksanakan Ujian Kompetensi berupa Ujian Profesi Advokat. Sedangkan di
Amerika Serikat, Penyelenggaraan Pendidikan Advokat dilaksanakan oleh sekolah hukum/perguruan tinggi. Sekolah hukum tersebut hanya melaksanakan, sedangkan dari kurikulumnya hingga ujian kompetensinya ditentukan dan dilaksanakan oleh Organisasi Advokat yang dalam hal ini adalah American Bar Association (ABA). ABA menentukan standar kurikum terhadap sekolah hukum yang menyelanggarakan pendidikan profesi advokat atau dikenal dengan Standart for Approval of Law School. Lebih lanjut lagi dalam seorang calon Advokat harus melalui ujian BAR di masing-masing yurisdiksi. ABA menerbitkan Comprehensive Guide to BAR Admission Requirements sebagai panduan mengenai persyaratan untuk memasuki Bar.

2. Pendidikan profesi Advokat di Indonesia seharusnya bukan dalam bentuk Pendidikan Khusus Profesi Advokat. Pendidikan Profesi Advokat sejatinya merupakan bentuk pendidikan profesi. Pengaturan pendidikan profesi secara umum sudah diakomodir dalam UU Pendidikan Tinggi. Dengan demikian, seharusnya penyelenggaraan pendidikan profesi advokat di Indonesia harus di transformasikan sesuai dengan Standar Pendidikan Profesi sebagaimana telah diatur dalam UU Pendidikan Tinggi, Peraturan Presiden No. 8 Tahun 2012 tentang Kerangka Kualifikasi Nasional 
Indonesia dan Permenristek Dikti No. 44 Tahun 2015 tentang Standar Nasional Pendidikan Tinggi. Sehingga standar kompetensi profesi advokat bisa tetap terjaga dan menghasilkan Advokat yang kompeten dalam bidangnya.

\section{DAFTAR PUSTAKA}

\section{Buku}

Alkostar, Artidjo, Peran dan Tantangan Advokat Dalam Era Globalisasi, Yogyakarta: UII Press, 2010.

Azhari. Negara Hukum Indonesia Analisis Yuridis Normatif Tentang Unsurunsurnya. Jakarta: U1 Press, 1995.

Blocher dan Bigs. The Cognitive Approach to Ethical Counseling. New York: State University of New York, 1986.

Dicey, V. Albert. Introduction to the Study of the Law of Consititution. $8^{\text {th }}$ Revised edition. Liberty Fund Inc,. 1982.

Dworkin, Ronald. Legal Research. Spring: Daedalus, 1973.

Konrad, Zweigert and Kotz Hein. Introduction to Comparative Law. 3d ed. Oxford: Clarendon Press, 1998.

McMorrow, A. Judith. Comparative Legal Education: An Introduction to US Legal Education and Preparation for the Practice of Law. Boston College Law School: Electronic Copy, 2009.

Moleong, J. Lexy. Metodologi Penelitian Kualitatif Edisi Revisi. Bandung: Remaja Rosdakarya, 2002.

Pinsler, Jeffrey. Ethic and Professional Responsibility, A Code For Advocate and Solicitor. Singapore: Academy
Publising, 2007.

Prent, K., et al. Kamus Latin-Indonesia. Yogyakarta: Kanisius, 1969.

Sarmadi, Sukris. Advokat Litigasi \& Non Litigasi Pengadilan. Bandung: Mandar Maju, 2009.

Pinsler, Jeffrey, Ethic and Professional Responsibility, A Code For Advocate and Solicitor, Singapore: Academy Publising, 2007.

\section{Jurnal}

Choudhry, Sujit. "Globalization in Search of Justification: Toward a Theory of Comparative Constitutional Interpretation." 74 Ind. L. J. 819, (1999): 825-826.

Raalf, Matthew S. "A Sheep in Wolf's Clothing: Why the Debate Surrounding Comparative Constitutional Law Is Spectacularly Ordinary." 73 Fordham L. Rev.: 1239, (Desember 2004): 12791281.

\section{Peraturan Perundang-undangan}

Undang-undang No. 18 Tahun 2003 tentang Advokat.

Undang-undang No. 48 Tahun 2009 tentang 


\section{Kekuasaan Kehakiman.}

Undang-undang No. 12 Tahun 2012 tentang Pendidikan Tinggi.

Peraturan Pemerintah No. 4 Tahun 2014 tentang Penyelenggaraan Pendidikan Tinggi dan Pengelolaan Perguruan Tinggi.

Peraturan Presiden No. 8 Tahun 2012 tentang Kerangka Kualifikasi Nasional Indonesia .

Peraturan Menteri Riset, Teknologi, dan Pendidikan Tinggi No. 44 Tahun 2015 tentang Standar Nasional Pendidikan Tinggi.

Keputusan Ketua Mahkamah Agung No. 73/ KMA/HK.01/IX/2015.

Peraturan Peradi No. 3 Tahun 2006 tentang Penyelenggaraan Pendidikan Khusus Profesi Advokat Putusan Mahkamah Konstitusi No. 014/PUU-IV/2006.

Putusan Mahkamah Konstitusi No. 015/ PUU-IV/2006.

Putusan Mahkamah Konstitusi No. 101/ PUU-VII/2009.

Putusan Mahkamah Konstitusi No. 66/ PUU-VIII/2010.

Putusan Mahkamah Konstitusi No. 112/ PUU-XII/2014.

Putusan Mahkamah Konstitusi No. 36/ PUU-XIII/2015.

Surat Ketua Mahkamah Agung No. 052/ KMA/V/2009.

Surat Ketua Mahkamah Agung No. 089/ KMA/VI/2010.

Surat Ketua Mahkamah Agung No. 73/KMA/ HK.01/IX/2015.

\section{Naskah Internet}

American Bar Association. "ABA Standard and Rules of Procedure for Approval of Law Schools 2015-2016", ”. http:// www.americanbar.org/content/dam/ aba/publications/misc/legal_education/ Standards/2015_2016_chapter_3. authcheckdam.pdf. Diakses 25 Juni 2016.

"History of the American Bar Association". http:// www.americanbar.org/content/aba/ about_the_aba/history.html. Diakses 25 Juni 2016.

Cipto, Hendra. Peradi Pecah Tiga, "MasingMasing Kubu Punya Ketua Umum”. http://nasional.kompas.com/ $\mathrm{read} / 2015 / 03 / 28 / 09095281 /$ Peradi . Pecah.Tiga.Masing-Masing.Kubu. Punya.Ketua.Umum. Diakses 13 Februari 2016.

McMorrow, Judith A. "Comparative Legal Education: An Introduction to US Legal Education and Preparation for the Practice of Law",. Boston College Law School, : Electronic Copy, 2009, . Ddalam http://ssrn.com/ abstract $=2076718$. Diakses 18 Juli 2016.

New York State Assitance Trust. "Are You Fit To Be A Lawyer". http://www.nylat. org/publications/brochures/documents/ characterandfitnessbrochure09.pdf. Diakses 5 Agustus 2016. 
Winarta, Frans Hendra. "Konflik Antar Pengurus Organisasi Advokat yang Berkepanjangan”. http:// www.hukumonline.com/berita/ baca/ho122359/konflik-antarpengurus-organisasi-advokat-yangberkepanjangan. Diakses 12 Februari 2016. 